\title{
PENGARUH APLIKASI BAKTERISIDA BERBAHAN AKTIF ASAM KLORO BROMO ISOSIANURIK 50\% TERHADAP INTENSITAS PENYAKIT HAWAR DAUN BAKTERI DAN PRODUKSI PADA TANAMAN PADI
}

\author{
Dani Bayu Aji Rizky Nugraha, Titik Nur Aeny \& Tri Maryono \\ Jurusan Agroteknologi, Fakultas Pertanian Universitas Lampung, \\ Jl.Prof. Soemantri Brodjonegoro, No.1, Bandar Lampung, 35145 \\ E-mail: danibayu30@gmail.com
}

\begin{abstract}
ABSTRAK
Penelitian bertujuan untuk mengetahui pengaruh aplikasi bakterisida berbahan aktif asam kloro bromo isosianurik $50 \%$ terhadap intensitas penyakit hawar daun bakteri pada tanaman padi. Penelitian ini dilaksanakan di Desa Wonodadi, Kecamatan Gadingrejo, Kabupaten Pringsewu, Lampung, pada bulan Desember 2012 sampai dengan Juni 2013. Perlakuan dalam percobaan ini disusun dalam rancangan acak kelompok (RAK) dengan empat perlakuan dan empat kelompok. Data yang diperoleh dianalisis menggunakan sidik ragam dan nilai tengah masing-masing perlakuan diuji dengan uji Duncan Multi Range Test (DMRT) pada $\alpha=0,05$. Hasil penelitian menunjukkan bahwa aplikasi bakterisida ini dapat menekan intensitas penyakit hawar daun bakteri pada tanaman padi varietas Ciherang di Lampung serta tidak menimbulkan gejala fitotoksisitas pada tanaman padi. Tingkat konsentrasi bakterisida $1,0 \mathrm{~g} \mathrm{l}^{-1}$ dan $1,5 \mathrm{~g} \mathrm{l}^{-1}$ secara nyata menurunkan keparahan penyakit hawar daun bakteri, namun tidak dapat mengurangi kehilangan hasil. Aplikasi bakterisida berpengaruh nyata terhadap nilai AUDPC, tetapi tidak berpengaruh nyata terhadap tinggi tanaman dan pertambahan jumlah anakan.
\end{abstract}

Kata kunci : Asam kloro bromo isosiaurik 50\%, hawar daun bakteri, intensitas penyakit.

\section{PENDAHULUAN}

Padi (Oryza sativa L.) merupakan salah satu tanaman pangan penting di Indonesia. Untuk memenuhi konsumsi beras nasional, selain melakukan impor dari negara-negara Asean seperti Kamboja, Vietnam, Myanmar, Laos, dan Thailand, pemerintah juga terus berusaha meningkatkan produksi beras dalam negeri (Asdhiana, 2012). Produktivitas padi rata-rata tahun 2011 di Indonesia hanya sekitar $49 \mathrm{ku} \mathrm{ha}^{-1}$ (Sutami, 2011), padahal potensi produktivitas padi dapat mencapai $80 \mathrm{ku} \mathrm{ha}^{-1}$ (Suprihatno et al., 2009).

Rendahnya produktivitas padi di Indonesia disebabkan oleh berbagai faktor, salah satunya adalah adanya penyakit hawar daun bakteri. Berbagai upaya pengendalian sudah dilakukan petani untuk mengatasi penyakit hawar daun bakteri pada tanaman padi, salah satunya adalah menggunakan bakterisida sintetik. Beberapa jenis bahan kimia berupa bakterisida dengan berbagai bahan aktif sudah banyak dipasarkan untuk digunakan oleh petani dalam mengendalikan penyakit pada tanaman padi.

Salah satu bahan aktif yang diketahui dapat digunakan untuk mengendalikan patogen tanaman adalah asam kloro bromo isosianurik (Chlorobromoisocyanuric Acid / CBIA). Pada awalnya bahan aktif ini dilaporkan sebagai mikrobiosida (Kegley et al., 2010), tetapi terdapat juga laporan tentang pengaruhnya terhadap patogen yang menyerang tanaman padi khususnya patogen hawar daun bakteri yang ada di Cianjur dan Karawang, Jawa Barat (Wibowo, 2010). Untuk lebih meyakinkan bahwa bakterisida berbahan aktif asam CBIA 50\% juga dapat menekan intensitas penyakit hawar daun bakteri pada tanaman padi di tempat lain, maka penelitian ini masih relevan untuk dilakukan.

\section{BAHAN DAN METODE}

Penelitian ini dilaksanakan di lahan pertanaman padi sawah di Desa Wonodadi, Kecamatan Gadingrejo, Kabupaten Pringsewu, Lampung, yang merupakan daerah endemik penyakit hawar daun bakteri. Penelitian ini dilaksanakan pada bulan Desember 2012 sampai dengan Juni 2013.Perlakuan dalam percobaan ini disusun menggunakan Rancangan Acak Kelompok (RAK) dengan empat kelompok yang ditentukan berdasarkan lokasinya. Penentuan lokasi setiap kelompok ditentukan atas dasar perbedaan kemiringan pada lahan. Perlakuan terdiri atas empat taraf konsentrasi formulasi bakterisida, yaitu kontrol (P0), konsentrasi $0,5 \mathrm{~g} \mathrm{l}^{-1}(\mathrm{P} 1)$, konsentrasi $1 \mathrm{~g} \mathrm{l}^{-1}$ (P2) dan konsentrasi 1,5 $\mathrm{g} \mathrm{l}^{-1}(\mathrm{P} 3)$. Setiap petak 
perlakuan berukuran $\pm 8 \mathrm{~m} \times 10 \mathrm{~m}$, sehingga total luasan petak percobaan adalah $1280 \mathrm{~m}^{2}\left(80 \mathrm{~m}^{2} \mathrm{x} 4\right.$ perlakuan $\mathrm{x} 4$ ulangan). Setiap petak perlakuan ditentukan secara acak pada masing-masing kelompok. Data yang diperoleh akan dianalisis dengan sidik ragam (Anova). Nilai tengah masing-masing perlakuan diuji dengan uji Duncan Multiple Range Test (DMRT) pada $\alpha=0,05$.

Varietas padi yang digunakan pada percobaan ini adalah varietas Ciherang. Varietas Ciherang merupakan salah satu varietas padi yang banyak ditanam oleh petani di Lampung, khususnya petani di Gading Rejo, Pringsewu. Bibit yang sudah siap tanam dicabut dari tempat persemaian dan ditanam pada plot-plot yang sudah disiapkan tanpa dipotong ujung-ujung daunnya. Penanaman bibit padi dilakukan pada tanggal 6 Desember 2012. Jarak tanam yang digunakan adalah $25 \mathrm{~cm}$ x $25 \mathrm{~cm}$ dengan sistem jajar legowo 6:1.

Aplikasi dilakukan dengan cara penyemprotan sebanyak tiga kali yaitu pada 14 hst, 28 hst dan 42 hst. Bakterisida yang diaplikasikan terlebih dahulu disuspensikan dalam air untuk mendapatkan konsentrasi yang diinginkan. Penyemprotan bakterisida dilakukan menggunakan knapsack sprayer dengan konsentrasi sesuai dengan perlakuan. Volume semprot yang digunakan adalah $3501 \mathrm{ha}^{-1}$. Pemupukan dilakukan dua kali dalam satu musim tanam. Pemupukan pertama dilakukan pada 10 hst menggunakan pupuk Urea dan SP36 dengan dosis masing-masing $100 \mathrm{~kg} \mathrm{ha}^{-1}$ dan 200 $\mathrm{kg} \mathrm{ha}^{-1}$. Pemupukan kedua dilakukan pada $35 \mathrm{hst}$ menggunkaan pupuk Urea dan NPK dengan dosis masing-masing $100 \mathrm{~kg} \mathrm{ha}^{-1}$ dan $200 \mathrm{~kg} \mathrm{ha}^{-1}$. Pada saat pemupukan kedua, diaplikasikan juga insektisida untuk mencegah serangan hama penggerek batang. Pengendalian hama dilakukan secara kimiawi sesuai dengan kebutuhan, dan pengendalian gulma dilakukan secara manual.

Pengamatan awal dilakukan pada 13 hst (satu hari sebelum aplikasi bakterisida) dan pengamatan selanjutnya dilakukan secara berkala setiap satu minggu sekali selama satu musim tanam. Penerokan dilakukan dengan mengamati 10 rumpun yang ditentukan pada tiap petak secara acak. Unit terok adalah 1 rumpun padi yang terdiri dari beberapa individu tanaman. Pengamatan pada setiap unit terok dilakukan setiap minggu untuk mengetahui peubah berikut:

1.Keparahan penyakit yang dihitung dengan rumus:

$$
\mathrm{KP}=\frac{\sum(\mathrm{n} \times \mathrm{v})}{\mathrm{N} \times \mathrm{Z}} \times 100 \%
$$

dengan $\mathrm{KP}=$ keparahan penyakit, $\mathrm{n}=$ jumlah rumpun yang terserang dalam setiap kategori serangan, $\mathrm{v}=$ kategori (skor) serangan, $\mathrm{N}=$ jumlah rumpun yang diamati, dan $\mathrm{Z}=$ kategori (skor) tertinggi yang digunakan.

Skoring ditentukan berdasarkan panduan sistem karakteristik dan evaluasi tanaman padi (diterjemahkan dari Standard Evaluation System (SES) for Rice edisi ke-4, 1996), yaitu 0 untuk tidak ada serangan (sangat tahan); 1 untuk serangan 1-5\% (tahan); 3 untuk serangan 6-12\% (agak tahan); 5 untuk serangan 13-25\% (sedang); 7 untuk serangan 26-50\% (agak rentan); dan 9 untuk serangan $51-100 \%$ (sangat rentan).

2. Area under disease progress curve (AUDPC) atau area di bawah kurva perkembangan penyakit (ABKPP). Penghitungan AUDPC dilakukan untuk mengetahui hubungan antara intensitas penyakit dengan waktu (Shaner \& Finney, 1977 dalam Zuraidah, 2011). AUDPC dihitung menggunakan rumus (Shaner \& Finney, 1977 dalam Jeger \& Viljanen-Rollinson, 2001):

$$
\text { AUDPC }=\sum_{i=1}^{n}\left[\frac{Y_{i+1}+Y_{i}}{2}\right]\left[X_{i+1}-X_{i}\right]
$$

dengan AUDPC = area under disease progress curve, $\mathrm{Y}_{\mathrm{i}}=$ intensitas penyakit pada pengamatan ke- $i$, $\mathrm{X}_{\mathrm{i}}=$ waktu (hari) pada pengamatan ke- $i$, dan $\mathrm{n}=$ total pengamatan.

3.Produksi tanaman padi, yang dihitung berdasarkan bobot gabah basah (sesaat setelah panen) dan bobot gabah kering (dua hari pengeringan/penjemuran).

4. Fitotoksisitas, yaitu gejala keracunan yang terjadi pada tanaman, sebagai akibat dari aplikasi suatu pestisida. fitotoksisitas diamati sejak aplikasi pertama pestisida untuk mengetahui ada tidaknya efek keracunan pada tanaman. Pengamatan fitotoksisitas dilakukan terhadap seluruh bagian tanaman yang menunjukkan gejala keracunan, seperti bercak-bercak atau gejala terbakar, dan dihitung persentase keterjadiannya.

5. Pertambahan jumlah anakan padi yang dilakukan pada 2 dan 7 minggu setelah tanam dan tinggi tanaman yang diamati pada fase pematangan susu.

\section{HASIL DAN PEMBAHASAN}

Gejala awal penyakit hawar daun bakteri mulai tampak pada saat tanaman berumur 4 minggu setelah tanam. Pada fase vegetatif ini, gejala yang tampak nyata berupa menguningnya beberapa daun tua. Pada fase reproduktif sampai pematangan, daun-daun yang 
bergejala menjadi kering dan berwarna cokelat jerami serta menggulung (Gambar 1).

Berdasarkan data keparahan penyakit hawar daun bakteri (HBD) dari 4 minggu setelah tanam sampai dengan pengamatan terakhir atau 12 minggu setelah tanam (Tabel 1 dan Tabel 2), diketahui bahwa aplikasi bakterisida berbahan aktif asam kloro bromo isosianurik dengan konsentrasi $1,0 \mathrm{~g} \mathrm{l}^{-1}$ dan 1,5 $\mathrm{g} \mathrm{l}^{-1}$ terbukti efektif menekan keparahan penyakit hawar daun bakteri. Tingkat konsentrasi $0,5 \mathrm{~g} \mathrm{l}^{-1}$ tidak dapat menekan keparahan penyakit sampai di bawah kontrol. Hasil ini agak berbeda dengan hasil percobaan yang dilakukan oleh Wibowo (2010) bahwa tingkat keparahan penyakit hawar daun bakteri pada 12 minggu setelah tanam hingga 14 minggu setelah tanam secara nyata lebih rendah dari keparahan penyakit pada tanaman kontrol.

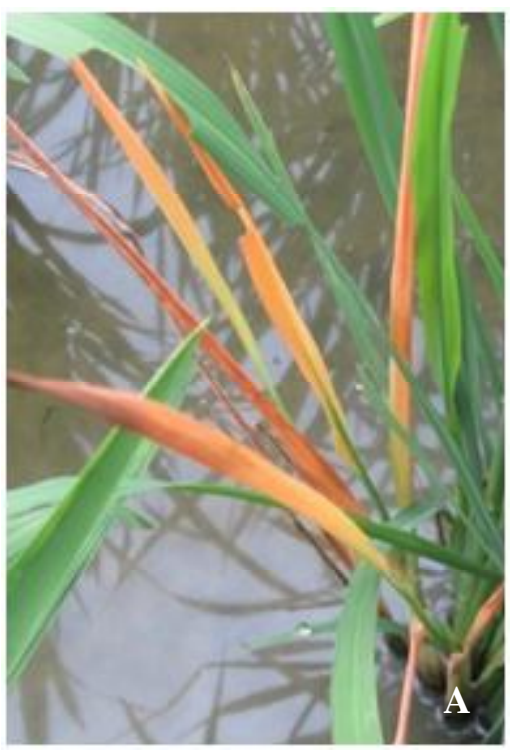

Secara umum dapat dikatakan bahwa pada fase vegetatif tingkat konsentrasi bakterisida berbahan aktif asam kloro bromo isosianurik 50\% yang berbeda tidak menyebabkan tingkat keparahan penyakit yang berbeda secara signifikan. Peningkatan konsentrasi dari $0,5 \mathrm{~g} \mathrm{l}^{-}$ ${ }^{1} \mathrm{ke} 1,5 \mathrm{~g} \mathrm{l}^{-1}$ tidak diikuti dengan menurunnya tingkat keparahan penyakit secara nyata. Namun demikian, pada fase reproduktif sampai pematangan, tingkat keparahan penyakit dipengaruhi oleh tingkat konsentrasi bakterisida yang digunakan. Tingkat konsentrasi $1,0 \mathrm{~g} \mathrm{l}^{-1}$ dan $1,5 \mathrm{~g}$ $\mathrm{l}^{-1}$ dapat menekan tingkat keparahan penyakit lebih baik dari tingkat konsentrasi $0,5 \mathrm{~g} \mathrm{l}^{-1}$, namun tingkat konsentrasi $1,5 \mathrm{~g} \mathrm{l}^{-1}$ ternyata tidak berbeda pengaruhnya dari tingkat konsentrasi $1,0 \mathrm{~g} \mathrm{l}^{-1}$. Jika dilihat dari hasil penghitungan nilai AUDPC (Tabel 3), tingkat konsentrasi bakterisida berbahan aktif asam kloro bromo isosianurik

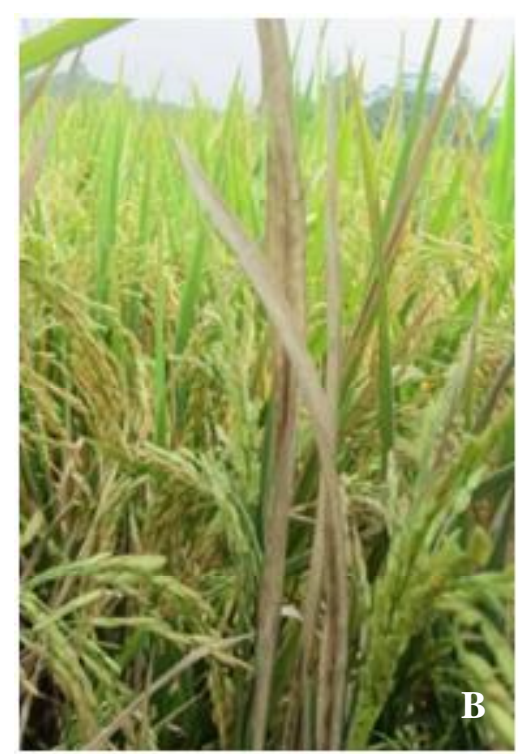

Gambar 1. Gejala penyakit hawar daun bakteri di lahan percobaan. $A=$ Fase vegetatif dan $B=$ fase reproduktif sampai pematangan (Sumber: Dokumentasi pribadi T.N. Aeny, 2013).

Tabel 1. Keparahan penyakit hawar daun bakteri pada fase vegetatif

\begin{tabular}{crrrc}
\hline \multirow{2}{*}{$\begin{array}{c}\text { Konsentrasi } \\
\text { bakterisida }\left(\mathrm{g} \mathrm{l}^{-1}\right)\end{array}$} & $4 \mathrm{mst}$ & $5 \mathrm{mst}$ & $6 \mathrm{mst}$ & $7 \mathrm{mst}$ \\
\cline { 2 - 5 } & $16,8 \mathrm{a}$ & $29,2 \mathrm{a}$ & $43,9 \mathrm{a}$ & $54,2 \mathrm{a}$ \\
0,5 & $2,5 \mathrm{~b}$ & $11,9 \mathrm{~b}$ & $18,9 \mathrm{~b}$ & $43,3 \mathrm{ab}$ \\
1,0 & $0 \mathrm{~b}$ & $6,9 \mathrm{~b}$ & $19,2 \mathrm{~b}$ & $33,1 \mathrm{~b}$ \\
1,5 & $3,1 \mathrm{~b}$ & $6,1 \mathrm{~b}$ & $22,2 \mathrm{~b}$ & $34,7 \mathrm{~b}$ \\
\hline Nilai $\mathrm{F}_{0,05}$ & $4,6^{*}$ & $4,4^{*}$ & $17,6^{*}$ & $6,0^{*}$ \\
\hline
\end{tabular}

Keterangan: Nilai tengah pada kolom yang sama yang diikuti huruf yang sama tidak berbeda nyata berdasarkan uji Duncan $\alpha=0,05 ; \mathrm{mst}=$ minggu setelah tanam. 
$50 \%$ yang semakin tinggi diikuti oleh nilai AUDPC yang semakin rendah. Namun demikian, nilai AUDPC pada tingkat konsentrasi $1,5 \mathrm{~g} \mathrm{l}^{-1}$ hanya sedikit lebih rendah daripada konsentrasi $1,0 \mathrm{gl}^{-1}$. Oleh karena itu, di dalam aplikasinya akan lebih efektif dan efisien jika menggunakan bakterisida berbahan aktif asam kloro bromo isosianurik 50\% dengan konsentrasi $1,0 \mathrm{~g} \mathrm{l}^{-1}$, karena dengan konsentrasi yang lebih tinggi $\left(1,5 \mathrm{~g} \mathrm{l}^{-1}\right)$ akan menyebabkan biaya pengeluaran yang lebih mahal, karena membutuhkan bahan kimia yang lebih banyak.

Perlakuan bakterisida dari berbagai konsentrasi tidak berpengaruh terhadap produksi tanaman padi (Tabel 4). Meskipun keparahan penyakit dapat ditekan, serta nilai AUDPC yang lebih rendah dari perlakuan kontrol, perlakuan aplikasi bakterisida memiliki bobot basah dan kering gabah sama dengan kontrol. Balai Besar Tanaman Padi (2009) menyebutkan bahwa setiap penurunan keparahan penyakit sebesar $10 \%$ akan mencegah kehilangan hasil tanaman padi sebesar $4,2 \%$. Pada penelitian ini, penurunan keparahan penyakit pada 12 minggu setelah tanam karena aplikasi bakterisida mencapai $5,9-22,2 \%$, tetapi hasil yang dapat diselamatkan hanya sebesar 2,5-6,3\% yang secara statistik tidak nyata. Meskipun keparahan penyakit hawar daun bakteri pada akhir pengamatan (12 minggu setelah tanam) mencapai 58,3-75,0\%, hasil produksi yang ditunjukkan dengan bobot kering tanaman padi masih berada pada kisaran potensi hasil varietas Ciherang yang mencapai 5-7 ton $\mathrm{ha}^{-1}$.

Pengamatan fitotoksisitas yang dilakukan sejak setelah aplikasi pertama bakterisida pada tanaman padi sampai dengan pengamatan terakhir, yaitu 13 minggu setelah tanam tidak ditemukan adanya gejala fitotoksisitas pada tanaman padi. Dengan demikian dapat dikatakan bahwa bakterisida berbahan aktif asam kloro bromo isosianurik tidak menyebabkan keracunan pada tanaman padi varietas Ciherang.

Perlakuan bakterisida dari berbagai tingkat konsentrasi yang diuji juga tidak berpengaruh terhadap pertumbuhan tanaman padi berdasarkan data tinggi tanaman dan pertambahan jumlah anakan. Meskipun keparahan penyakit pada semua perlakuan sampai dengan tujuh minggu setelah tanam mencapai 34,7 $54,2 \%$, namun tinggi tanaman dan pertambahan jumlah anakan masih berada pada kisaran potensi varietas Ciherang. Potensi tinggi tanaman varietas Ciherang ratarata mencapai $107-115 \mathrm{~cm}$, sedangkan potensi anakan produktif varietas Ciherang mencapai 14-17 batang/ rumpun (Suprihatno et al., 2009).

Tabel 3. Nilai AUDPC penyakit hawar daun bakteri sampai dengan $12 \mathrm{mst}$

\begin{tabular}{cc}
\hline Konsentrasi bakterisida $\left(\mathrm{g}^{-1}\right)$ & AUDPC \\
\hline 0,0 & 33,3 \\
0,5 & 26,2 \\
1,0 & 22,5 \\
1,5 & 22,0 \\
\hline
\end{tabular}

Tabel 4. Data tinggi tanaman, jumlah anakan dan produksi tanaman padi

\begin{tabular}{ccccc}
\hline \multirow{2}{*}{$\begin{array}{c}\text { Konsentrasi } \\
\text { bakterisida }\left(\mathrm{g} \mathrm{l}^{-1}\right)\end{array}$} & \multicolumn{2}{c}{ Produksi $\left(\text { ton }^{-1}\right)^{-1}$} & $\begin{array}{c}\text { Tinggi tanaman pada } \\
7 \text { mst }(\mathrm{cm})\end{array}$ & $\begin{array}{c}\text { Pertambahan } \\
\text { jumlah anakan }\end{array}$ \\
\cline { 2 - 3 } & $\begin{array}{c}\text { Babah } \\
\text { gabah }\end{array}$ & 6,68 & 119,1 & 20,6 \\
0 & 8,13 & 6,85 & 118,1 & 21,2 \\
0,5 & 8,73 & 6,89 & 120,8 & 21,9 \\
1,0 & 8,76 & 7,10 & 121,5 & 20,8 \\
\hline Nilai $\mathrm{F}_{0,05}$ & 9,03 & $2,2^{\text {tn }}$ & $1,0^{\text {tn }}$ & $0,5^{\text {tn }}$ \\
\hline
\end{tabular}




\section{KESIMPULAN}

Aplikasi bakterisida berbahan aktif asam kloro bromo isosianurik 50\% dapat menekan keparahan penyakit hawar daun bakteri pada tanaman padi varietas Ciherang. Tingkat konsentrasi bakterisida $1,0 \mathrm{~g} \mathrm{l}^{-1}$ dan $1,5 \mathrm{~g} \mathrm{l}^{-1}$ secara nyata menurunkan keparahan penyakit hawar daun bakteri, namun tidak dapat menurunkan kehilangan hasil tanaman padi. Aplikasi bakterisida juga berpengaruh nyata terhadap nilai AUDPC, tetapi tidak berpengaruh nyata terhadap tinggi tanaman, jumlah anakan, dan hasil produksi tanamann padi.

\section{DAFTAR PUSTAKA}

Asdhiana, I.M. 2012. Mendag Imbau Kurangi Konsumsi Beras.Dalam:http://bisniskeuangan. kompas.com/read/2012/08/31/18413754/ Mendag.ImImb.Kurangi.Konsumsi.Beras. Diakses tanggal 8 Desember 2012.

Balai Besar Penelitian Tanaman Padi (BB Padi). 2009. Penyakit Hawar Daun Bakteri (BLB). Dalam: http://bbpadi.litbang.deptan.go.id/index.php/ in/ penyakit-padi-karena-bakteri/204penyakit-hawar-daun-bakteri-blb-.html. Diakses tanggal 8 Desember 2012.

International Rice Research Institute (IRRI). 1996. Sistem Karakterisasi dan Evaluasi Tanaman Padi. Diterjemahkan dari Standard Evaluation System (SES) for Rice, $4^{\text {th }}$ edition. Penerjemah: T.S. Silitonga, I.H. Somantri, A.A. Daradjat, dan H. Kurniawan. Departemen Pertanian. Bogor. ISBN 979-8393-03-1.
Jeger, M.J. and S.L.H. Viljanen-Rollinson. 2001. The Use of The Area Under The Disease-Progress Curve (AUDPC) to Assess Quantitative Disease Resistance in Crop Cultivars.Theory Appl Genet (2001) 102:32-40.

Kegley, S.E., B.R. Hill, S. Orme, and A.H. Choi. 2010. Bromo chloro isocyanuric acid - Identification, toxicity, use, water pollution potential, ecological toxicity and regulatory information.PAN Pesticides Database - Chemicals. Dalam: http:/ /www.pesticideinfo.org/Detail_... Diakses tanggal 8 Desember 2012.

Suprihatno, B., A.A. Daradjat, Satoto, I.N. Widiarta, A. Setyono, S.D. Indrasari, O.S. Lesmana, dan H. Sembiring. 2009. Deskripsi Varietas Padi. Balai Besar Penelitian Tanaman Padi. Subang. 105 hlm.

Sutami. 2011. Upaya Optimalisasi Potensi Padi Hibrida (SL-PHT di POKTAN Karangan Krajan desa Karangan Kec. Bareng). Dinas Pertanian Kabupaten Jombang. Dalam: http://pertanian. jombangkab.go.id/berita-dinas/kecamatan/ 143-upaya-optimalisasi-potensi-.... Diakses tanggal 5 Desember 2012.

Wibowo, B.S. 2010. Penyakit Blast dan Hawar Daun Bakteri (HBD) dan Hasil Pengujian. Balai Besar Peramalan Organisme Pengganggu Tumbuhan (BBPOPT). Jatisari.

Zuraidah. 2011. Potensi beberapa bakteri penghambat pertumbuhan Xanthomonas oryzae pv. oryzae penyebab penyakit hawar daun bakteri pada tanaman padi. Tesis. Sekolah Pascasarjana Institut Pertanian Bogor. 